Uji Daya Hambat Ekstrak Daun Jamblang (Syzygium Cumini (L.) Skeels) Terhadap Pertumbuhan Bakteri Streptococcus Pyogenes dan Proteus Mirabilis

\title{
Inhibitory Test of Jamblang Leaf Extract (Syzygium Cumini (L.) Skeels) Against the Growth of Streptococcus Pyogenes and Proteus Mirabilis Bacteria
}

\author{
VENNY PATRICIA \\ WAWAN SOFWAN ZAINI \\ AHMAD YANI \\ SITI ATIKAH
}

\author{
Jurusan Teknologi Laboratorium Medis Poltekkes Kemenkes Banten \\ Jl. DR. Sitanala, Karang Sari, Kec. Neglasari, Tangerang, Banten \\ Email : venny.tlmpolkesten@gmail.com
}

\begin{abstract}
Abstrak
Penyakit infeksi merupakan masalah bagi kesehatan masyarakat dan dapat meningkatkan morbiditas dan mortalitas pasien. Bakteri yang menyebabkan penyakit infeksi diantaranya yaitu Streptococcus pyogenes dan Proteus mirabilis. Penggunaan antibiotik yang tidak tepat dapat menimbulkan masalah resistensi dan efek obat yang tidak dikehendaki. Ekstrak daun Jamblang (Syzygium cumini) dapat digunakan sebagai obat antibakteri alami. Ada sebuah penelitian menunjukkan kandungan senyawa aktif pada daun Jamblang adalah Flavonoid, tannin, alkaloid, dan saponin merupakan komponen senyawa kimia yang diduga sebagai antibakteri. Penelitian ini bertujuan untuk mengetahui aktivitas antibakteri ekstrak daun Jamblang terhadap bakteri Streptococcus pyogenes dan Proteus mirabilis. Metode yang digunakan adalah metode Konsentrasi Hambat Minimum dengan cara difusi sumuran. Penelitian menggunakan ekstrak daun Jamblang dengan variasi konsentrasi 10\%, 20\%, 30\%, dan 40\%, bakteri uji yang digunakan adalah Streptococcus pyogenes dan Proteus mirabilis, menggunakan kontrol positif kloramfenikol, dan kontrol negatif DMSO 10\%. Hasil penelitian menunjukkan bahwa ekstrak daun Jamblang dapat menghambat pertumbuhan bakteri Streptococcus pyogenes dan Proteus mirabilis pada semua variasi konsentrasi. Pada uji statistik Non-Parametrik Kruskall Wallis kedua bakteri tersebut didapatkan $\mathrm{P}<0,05$. Pada bakteri Streptococcus pyogenes nilai $\mathrm{P}=0,031$, dan bakteri Proteus mirabilis nilai $\mathrm{P}=0,015$. Hasil tersebut menunjukkan adanya perbedaan yang nyata pada penelitian ini.
\end{abstract}

Kata Kunci : Streptococcus Pyogenes ; Proteus mirabilis ; Daun Jamblang (Syzygium cumini) ; Uji Daya Hambat

\section{Abstract}

Infectious diseases are a problem for public health and can increase patient morbidity and mortality. Bacteria that cause infectious diseases include Streptococcus pyogenes and Proteus mirabilis. Inappropriate use of antibiotics can cause resistance problems and the effects of undesirable drugs. Jamblang (Syzygium cumini) leaf extract can be used as a natural antibacterial drug. There is a study showing the content of active compounds in the leaves of Jamblang are Flavonoids, tannins, alkaloids, and saponins are components of chemical compounds that are suspected as antibacterial. This study aims to determine the antibacterial activity of Jamblang leaf extract against Streptococcus pyogenes and Proteus mirabilis bacteria. The method used is the Minimum Inhibitory Concentration method using well diffusion. The study used Jamblang leaf extract with various concentrations of $10 \%$, $20 \%, 30 \%$, and 40\%, the test bacteria used were Streptococcus pyogenes and Proteus mirabilis, using positive control of chloramphenicol, and negative control of 10\% DMSO. 
The results showed that Jamblang leaf extract can inhibit the growth of Streptococcus pyogenes and Proteus mirabilis bacteria in all concentrations. In the Kruskall Wallis Non-Parametric statistical test the two bacteria obtained $P<0.05$.In Streptococcus pyogenes bacteria the value of $P=0.031$, and Proteus mirabilis bacteria the value of $P=0.015$. These results indicate a real difference in this study.

Keywords: Streptococcus pyogenes ; Proteus mirabilis ; Jamblang (Syzygium cumini) Leaves ; Inhibitory Test

\section{Pendahuluan}

Indonesia merupakan Negara tropis yang berpotensi endemik penyakit infeksi yang setiap saat dapat menjadi ancaman bagi kesehatan masyarakat. Manusia termasuk salah satu makhluk hidup yang paling rentan terhadap infeksi bakteri, di antaranya yaitu Streptococcus pyogenes dan Proteus mirabilis. Bakteri Streptococcus pyogenes merupakan bakteri yang paling sering menginfeksi saluran pernapas atas (ISPA) yaitu faringitis (Marhamah et al., 2018). Bakteri Proteus mirabilis merupakan salah satu Gram negatif yang menyebabkan infeksi saluran kemih (ISK) (Mufida, 2010). Pengobatan penyakit infeksi bakteri sebagian besar menggunakan antibiotik. Di Negara berkembang $30-80 \%$ penderita yang dirawat di rumah sakit mendapat terapi antibiotik. Akan tetapi $20-65 \%$ penggunaannya dianggap tidak tepat. Penggunaan yang tidak tepat dapat menimbulkan masalah resistensi dan efek obat yang tidak dikehendaki (Musdalipah, 2018). Oleh karena itu, perlu dikembangkan alternatif pengobatan dengan menggunakan bahan alam yang diharapkan lebih efektif, efisien dan aman. Salah satu jenis tumbuhan yang dapat dijadikan sebagai obat alami adalah tumbuhan Jamblang (Syzygium cumini), tumbuhan Jamblang dilaporkan mengandung senyawa kimia antara lain suatu alkaloid, flavonoid, resin, tannin, dan minyak atsiri, yang berfungsi sebagai anti mikroba, obat infeksi pada luka, anti jamur, anti virus, anti kanker, dan anti tumor (Dewi and Wahyuni, 2018). Berdasarkan latar belakang yang menyebutkan bahwa daun Jamblang memiliki efek sebagai antibakteri, maka peneliti tertarik untuk melakukan penelitian tentang uji daya hambat ekstrak daun Jamblang (Syzygium cumini) terhadap bakteri Gram positif Streptococcus pyogenes dan bakteri Gram negatif Proteus mirabilis pada konsentrasi 10\%, $20 \%, 30 \%$, dan $40 \%$ dengan menggunakan metode difusi sumuran..

\section{Metode}

Penelitian ini bersifat eksperimental laboratorik, dengan metode Difusi sumuran dalam uji sensitifitas bakteri Streptococcus pyogenes dan Proteus mirabilis terhadap ekstrak daun Jamblang (Syzygium cumini). Penelitian ini menggunakan perlakuan dengan tiga kali pengulangan dari empat variasi konsentrasi. Adapun tahapan penelitian sebagai berikut: 1) Peremajaan Bakteri Streptococcus pyogenes dan Proteus mirabilis dengan menggunakan Nutrient agar miring Selanjutnya inokulasi masing - masing bakteri pada media miring menggunakan kawat ose dan inkubasi dalam inkubator pada suhu $37^{\circ} \mathrm{C}$ selama 24 jam (Adilang et al., 2019). Tahap ke 2) Pembuatan Ekstrak Daun Jamblang yaitu : Daun Jamblang segar yang telah dipetik dibersihkan dari kotoran, dicuci dengan air sampai bersih dan ditiriskan, kemudian dipotong-potong menjadi ukuran lebih kecil. Daun Jamblang tersebut dikeringkan dengan cara diangin-anginkan di udara terbuka yang terlindungi dari sinar matahari hingga benar-benar kering, daun Jamblang yang telah kering kemudian dihancurkan dengan menggunakan blender sampai berbentuk serbuk. Pembuatan ekstrak etanol daun Jamblang dilakukan dengan cara 500 gram serbuk simplisia daun Jamblang diekstraksi dengan menggunakan etanol 70\% dengan perbandingan 1:5 dimasukkan kedalam wadah. Lalu diaduk/mixer sampai homogen \pm 3 jam dan diamkan endapan selama 24 jam, kemudian pisahkan ampas dengan filtrat. Tambahkan etanol $70 \%$ pada ampas dan aduk \pm 1 
jam, kemudian saring dan pisahkan antara ampas dengan filtrat. Filtrat 1 dan 2 disatukan, kemudian di evaporasi dengan menggunakan rotary evaporator pada temperatur $\pm 400 \mathrm{C}$. Ekstrak yang telah jadi di timbang untuk mengetahui seberapa besar ekstrak yang di hasilkan dari proses ekstraksi. Semua ekstrak disimpan di lemari es pada suhu 40C untuk penggunaam kedepan. Serbuk yang diekstraksi dilarutkan dalam 10\% dimethyl sulfoxida (DMSO). Konsentrasi variasi ekstrak daun jambang dapat dilihat pada tabel 1.

\section{Tabel 1 : Konsentrasi Ekstrak Daun Jamblang (Syzygium cumini)}

\begin{tabular}{cccc}
\hline No & $\begin{array}{c}\text { Konsentrasi } \\
(\%)\end{array}$ & $\begin{array}{c}\text { Ekstrak daun } \\
\text { Jamblang (gram) }\end{array}$ & $\begin{array}{c}\text { Volume DMSO 10\% } \\
(\mathrm{ml})\end{array}$ \\
\hline 1. & $40 \%$ & 0,4 & 1 \\
2. & $30 \%$ & 0,3 & 1 \\
3. & $20 \%$ & 0,2 & 1 \\
4. & $10 \%$ & 0,1 & 1 \\
\hline
\end{tabular}

Tahap ke 3 pengujian ekstrak menggunakan metode difusi sumuran yaitu: Pembuatan media Mueller Hinton Agar (MHA), pembuatan suspensi bakteri 0,5 Mc Farland dan disebar merata dengan menggunakan kapas lidi steril lalu membuat sumuran pada media MHA dengan ukuran diameter lubang $5 \mathrm{~mm}$. Ekstrak daun jamblang dimasukkan ke lubang sumuran menggunakan mikropipet sebanyak $50 \mu \ell$. Kontrol negatif yaitu $50 \mu \ell$ DMSO 10\%; kontrol positif $50 \mu \ell$ antibiotik kloramfenikol; Perlakuan P1 konsentrasi 40\%; P2 konsentrasi 30\%; P3 konsentrasi 20\% dan P4 konsentrasi 10\% pada masing-masing lubang pada sumuran. Media Mueller Hinton Agar diinkubasi selama 24 jam pada suhu $37^{\circ} \mathrm{C}$. Zona bening yang terbentuk disekitar sumuran diamati dan diukur menggunakan penggaris.

\section{Hasil dan Pembahasan}

Berdasarkan penelitian tentang daya hambat ekstrak daun Jamblang terhadap pertumbuhan bakteri Streptococcus pyogenes dan Proteus mirabilis yang di lakukan 3 kali pengulangan pada variasi konsentrasi $40 \%, 30 \%, 20 \%, 10 \%$, kontrol (+) dan kontrol (-). Pengujian dengan menggunakan bakteri $S$. pyogenes disajikan pada tabel 2 dan hasil sumuran yang sudah diinkubasi dapat dilihat pada Gambar 1. Sedangkan pengujian dengan menggunakan P. mirabilis disajikan pada tabel 3 dan hasilnya ditampilkan pada gambar 2 .

Berdasarkan tabel 1 daya hambat ekstrak daun Jamblang pada bakteri Streptococcus pyogenes dengan konsentrasi $10 \%$ dari 3 kali pengulangan terdapat rata-rata diameter zona hambat yaitu 15,7 mm dan dikategorikan kuat. Pada konsentrasi 20\% dari 3 kali pengulangan terdapat rata-rata diameter zona hambat yaitu $17 \mathrm{~mm}$ dan dikategorikan kuat. Pada konsentrasi $30 \%$ dari 3 kali pengulangan terdapat rata-rata diameter zona hambat yaitu 18,7 $\mathrm{mm}$ dan dikategorikan kuat. Pada konsentrasi $40 \%$ dari 3 kali pengulangan terdapat rata-rata diameter zona hambat yaitu 19,3 $\mathrm{mm}$ dan dikategorikan kuat. Hasil dapat dilihat pada tabel dan gambar dibawah ini: 


\section{a. Analisis Univariat}

Tabel 2 diameter zona hambat ekstrak daun Jamblang (Syzygium cumini) terhadap Streptococcus pyogenes

\begin{tabular}{cccccc}
\hline & \multicolumn{5}{c}{ Diameter Daya Hambat (mm) } \\
Konsentrasi (\%) & 1 & 2 & 3 & Jumlah & Rata-Rata \\
\hline 10 & 15 & 16 & 16 & 47 & 15,7 \\
20 & 16 & 17 & 18 & 51 & 17 \\
30 & 18 & 18 & 20 & 56 & 18,7 \\
40 & 19 & 19 & 20 & 58 & 19,3 \\
Kontrol Positif (+) & 18,7 & 18,7 & 18,7 & 56,1 & 18,7 \\
Kontrol Negatif (-) & - & - & - & - & - \\
\hline
\end{tabular}

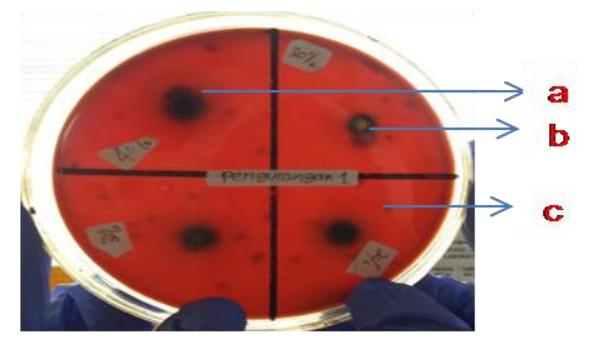

Pengulangan 1 : Uji Penelitian

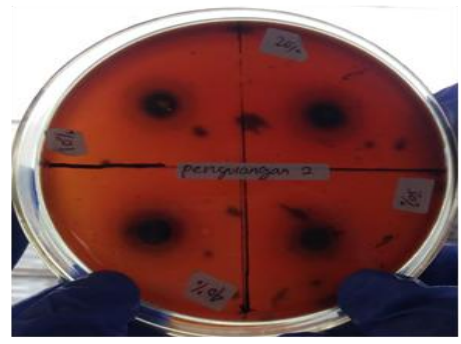

Pengulangan 2 : Uji Penelitian

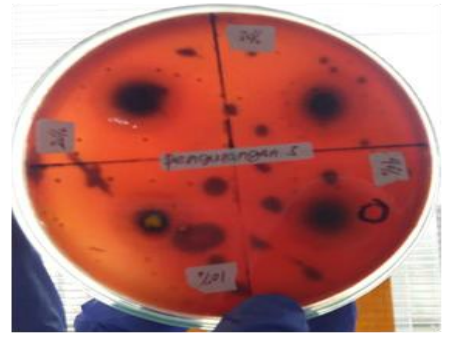

Pengulangan 3 : Uji Penelitian

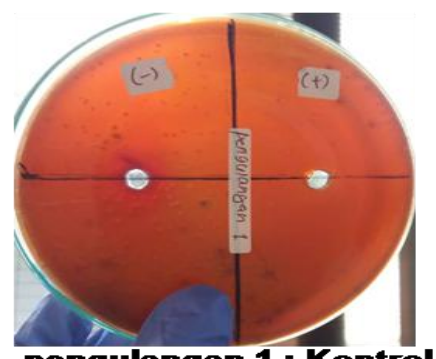

pengulangan 1 : Kontrol

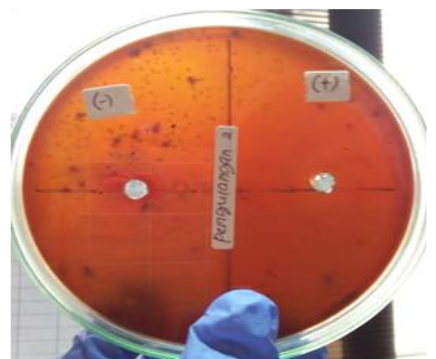

pengulangan 2 : Kontrol

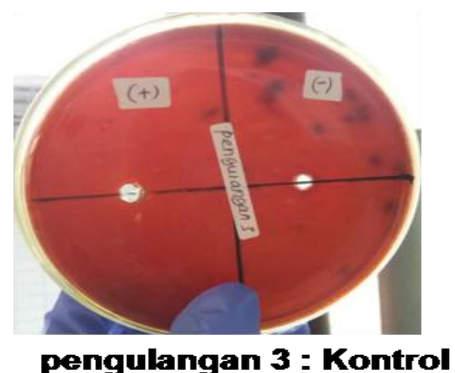

Gambar 1 Aktivitas antibakteri ekstrak daun Jamblang (Syzygium cumini) terhadap Streptococcus pyogenes. Zona Bening, (b) Ekstrak daun Jamblang, (c) Biakan Bakteri.

Pada bakteri Proteus mirabilsi dengan konsentrasi 10\% dari 3 kali pengulangan terdapat rata-rata diameter zona hambat yaitu $19,3 \mathrm{~mm}$ dan dikategorikan kuat. Pada konsentrasi $20 \%$ dari 3 kali pengulangan terdapat rata-rata diameter zona hambat yaitu 20,7 mm dan dikategorikan sangat kuat. Pada konsentrasi 30\% dari 3 kali pengulangan terdapat rata-rata diameter zona hambat yaitu $22,3 \mathrm{~mm}$ dan dikategorikan sangat kuat. Pada konsentrasi $40 \%$ dari 3 kali pengulangan terdapat rata-rata diameter zona hambat yaitu $24 \mathrm{~mm}$ dan dikategorikan sangat kuat. Hasil dapat dilihat pada Tabel 3 dan Gambar 2 dibawah ini: 
Tabel 3 Diameter zona hambat ekstrak daun Jamblang terhadap Proteus mirabilis

Diameter Daya Hambat (mm)

Konsentrasi (\%)

Proteus mirabilis

\begin{tabular}{cccccc} 
& 1 & 2 & 3 & Jumlah & Rata-Rata \\
\hline 10 & 20 & 19 & 19 & 58 & 19,3 \\
20 & 21 & 21 & 20 & 62 & 20,7 \\
30 & 22 & 22 & 23 & 67 & 22,3 \\
40 & 24 & 24 & 24 & 72 & 24 \\
Kontrol Positif(+) & 29 & 29 & 29 & 87 & 29 \\
Kontrol Negatif(-) & - & - & - & - & - \\
\hline
\end{tabular}

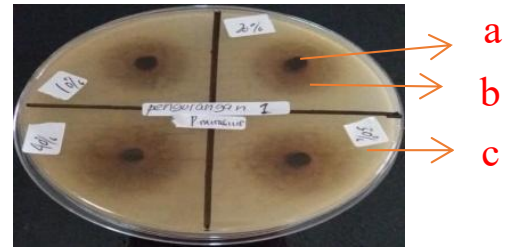

Pengulangan 1 : Uii Penelitian

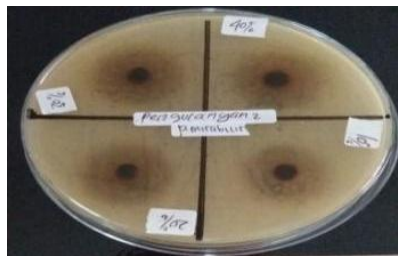

Pengulangan 2 : Uji Penelitian

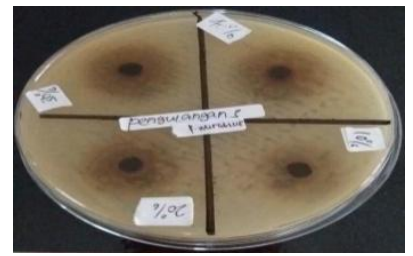

Pengulangan 3 : Uji Penelitian

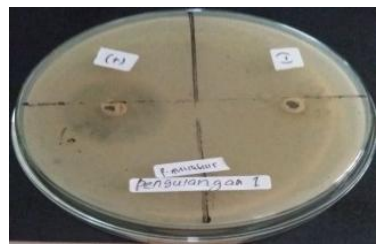

Pengulangan 1 : Kontrol

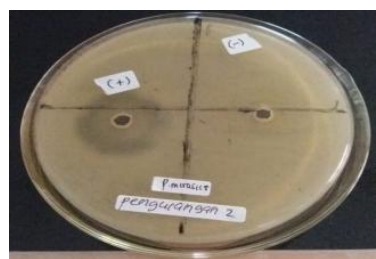

pengulangan 2 : Kontrol

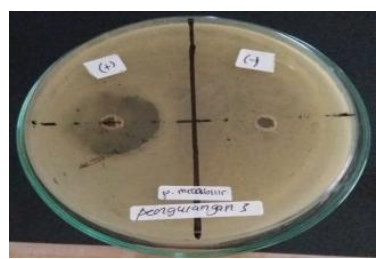

pengulangan 3 : Kontrol

Gambar 2 Aktivitas antibakteri ekstrak daun Jamblang (Syzygium cumini) terhadap Proteus mirabilis (a) Ekstrak daun Jamblang, (b) zona bening, (c) biakan bakteri.

\section{b. Analisis Bivariat}

Hasil penelitian manunjukkan bahwa aktivitas ekstrak daun Jamblang dapat menghambat pertumbuhan bakteri Streptococcus pyogenes dan Proteus mirabilis diperoleh hasil yang berbeda nyata dengan dilakukannya uji Non-Parametrik Test menggunakan Kruskall Wallis pada taraf uji 5\% $(\mathrm{P}<0,05)$. Pada bakteri Streptococcus pyogenes diperoleh hasil Asymp.Sig. 0,031, dimana hasil tersebut menunjukkan $(\mathrm{P}<0,05)$. Hasil dapat dilihat pada grafik Gambar 3 dan Tabel 4 dibawah ini: 


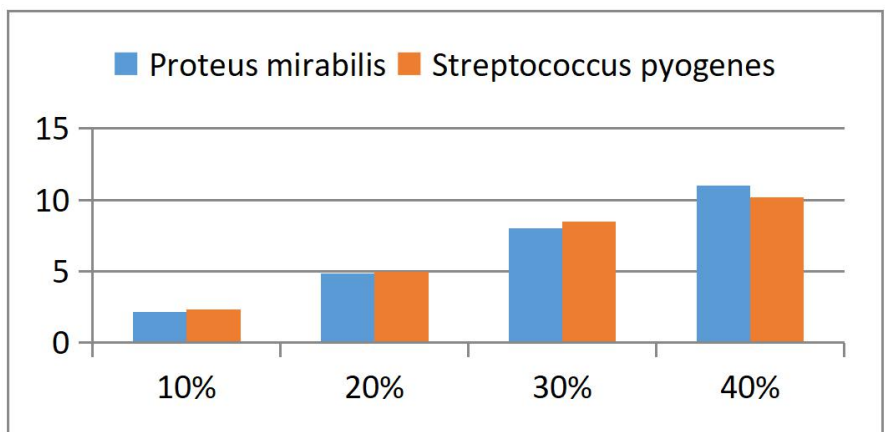

Gambar 3. Ranks Kruskal-Wallis Test

Tabel 4 : Hasil Uji Analisis Kruskal-Wallis Test Test Statistics

\begin{tabular}{ccc}
\hline & S. pyogenes & P. mirabilis \\
\hline Chi-Square & 8.861 & 10.459 \\
Df & 3 & 3 \\
\hline Asymp. Sig. & .031 & .015 \\
\hline
\end{tabular}

Daun Jamblang mempunyai khasiat sebagai antibakteri, dimana telah dilakukan sebelumnya oleh Tahir, L. (2012) bahwa ekstrak daun Jamblang memiliki aktivitas antibakteri terhadap Streptococccus viridans, Streptococcus mutans, Escherichia coli, Pseudomonas aerugenosa, Staphylococcus aureus dan Bacillus subtilis. Zona hambat yang terbentuk disebabkan kandungan senyawa aktif yang terdapat dalam daun Jamblang. Menurut penelitian yang dilakukan oleh Taher (2012) menyebutkan bahwa ekstrak daun Jamblang mengandung senyawa alkaloid, flavonoid, minyak atsiri, terpenoid, steroid, fenolik dan saponin.

\section{Simpulan dan Saran}

\section{Simpulan}

Ekstrak daun Jamblang mempunyai potensi sebagai obat alternatif terhadap bakteri Streptococcus pyogenes dan Proteus mirabilis pada konsentrasi 10\%, 20\%, 30\%, dan 40\%. Konsentrasi yang paling efektif pada konsentrasi $40 \%$ terhadap kedua bakteri.

\section{Saran}

Penelitian ini dapat dilanjutkan lebih lanjut untuk pengujian secara in vivo untuk melihat keefektifan nya lebih baik lagi pada konsentrasi yang paling terbaik. Selain itu disarankan untuk mengganti variabel terikatnya pada fungi atau bakteri selain Streptococcus pyogenes dan Proteus mirabilis, mengganti metode, dan juga mengganti bagian dari tumbuhan jamblang seperti buah, biji, batang, dan akar yang belum pernah di teliti sebelumnya.

\section{Daftar Pustaka}

Adilang CL, pelealu N, Citraningtyas G. (2019). Uji Aktivitas Antibakteri Ekstrak Etanol Batang Dan Pelepah Daun Tanaman Pisang Ambon ( Musa paradisiaca var sapientum (L.) Kunt ) Terhadap Bakteri Staphlyococcus aureus. Jurnal Ilmiah Farmasi. 8 (3) : 159.

Dewi STR, dan Wahyuni S. (2018). Uji Efek Anti Inflamasi Rebusan Daun Jamblang (Syzygium cumini) Pada Mencit (Mus musculus). Media Farmasi. XIV(1):53. 
Fahrurriza, F. R., \& dkk. (2020). Gambaran Escherichia Coli Pada Air Sumur Gali. Jaringan Laboratorium Medis, 02(01), 1-5.

Karlina, E., Widodo, \& Purlinda, D. E. (2019). Biokimia Mycobacterium Tuberculosis yang Diberi Perlakuan Obat Anti TB Isoniazid. Jaringan Laboratorium Medis, 1(2), 81-85.

Langsat (Lansium domesticum L.). Skripsi. UNG.

Marhamah, Putri IW. (2018). Efektivitas Ekstrak Batang Pisang Kepok (Musa x paradisiaca Linn.) Terhadap Pertumbuhan Bakteri Streptococcus pyogenes. Jurnal Analis Kesehatan. 7 (1) : 706.

Mufida DC, Sumarno, \& Santoso S. (2010). Identifikasi Protein Adhesi Pili Proteus Mirabilis P355 dan Protein Reseptor pada Vesika Urinaria Kelinci,Jurnal 1(1), 3-8.

Musdalipah. (2018). Identifikasi Drug Related Problem (Drp) Pada Pasien Infeksi Saluran Kemih Di Rumah Sakit Bhayangkara Kendari. Jurnal Kesehatan. 11(1): 40.

Saputro, A. V. R. (2019). Pemeriksaan MPN ( Most Probable Number ) Coliform dan Identifikasi Escherichia Coli pada Jamu Gendong Beras Kencur. Jaringan Laboratorium Medis, 01(01), 11-15.

Sumiati, D., \& Budiharjo, T. (2019). Hasil Temuan Suspect BTA Sebelum dan Sesudah Program Ketuk Pintu oleh Kader Berdasarkan Kualitas Sampel Dahak. Jaringan Laboratorium Medis, 01(01), 34-37.

Taher, Tamrin. (2011). Identifikasi Senyawa Flavonoid dari Ekstrak Metanol Kulit Batang.

Tahir, L. (2012). Effect Of Leaves Extract Of Indigenous Species Of Syzygium cumini on Dental aries Causing Patogens. I. Journal of Pharma and Bio Sciences $: 1$. 